\title{
PEMBUATAN NANOZEOLIT ALAM PAHAE MENGGUNAKAN ALAT PLANETARY BALL MILLING
}

Julizar Muttaqin dan Makmur Sirait*

Jurusan Fisika, Fakultas Matematika dan Ilmu Pengetahuan Alam, Universitas Negeri Medan, Indonesia

\begin{abstract}
Abstrak
Penelitian ini bertujuan untuk membuat nanozeolit alam Pahae dengan menggunakan Planetary Ball Milling. Zeolit diambil dari Pahae, kemudian digerus lalu diayak dengan 200 mesh, dicuci dengan aquades. Kemudian diaktivasi secara kimia dengan melarutkan ke dalam $\mathrm{HCl} 2$ molar dengan perbandingan $1: 3 \mathrm{~b} / \mathrm{v}$. Diaktivasi secara fisika dengan mensintering pada suhu $500{ }^{\circ} \mathrm{C}$ selama $2 \mathrm{jam}$. Zeolit yang telah dikeringkan dimasukan dalam Planetary Ball Milling dengan kecepatan $500 \mathrm{rpm}$ selama 8 jam, $16 \mathrm{jam}$, dan $24 \mathrm{jam}$. Analisis XRD ditemukan pola difraksi berbentuk amorf dan dengan menggunakan persamaan scherrer diperoleh ukuran rata-rata partikel zeolit sebesar 85,44 $\mathrm{nm}$ pada penggilingan selama $24 \mathrm{jam}$. Hasil SEM menunjukkan permukaaan nanozeolit masih ada menggumpal (aglomerasi) dan ukurannya kurang merata. Hasil EDX diperoleh kandungan zeolit terdiri dari silikon (43,75\%), Oksigen (42,66\%), Aluminium dan (7,72\%), Besi $(6,39 \%)$, dan Kalium $(3,3 \%)$
\end{abstract}

Kata kunci : Nanozeolit, Planetary Ball Milling, XRD, SEM, EDX

How to Cite: Julizar Muttaqin dan Makmur Sirait, (2015), Pembuatan Nanozeolit Alam Pahae Menggunakan Alat Planetary Ball Milling, Jurnal Einsten Prodi Fisika FMIPA Unimed, 3 (2): 45-50. 


\section{PENDAHULUAN}

Nanopartikel merupakan pembuatan material dengan ukuran kurang dari $100 \mathrm{~nm}$ dan melahirkan sifat-sifat atau fungsi yang baru pada material tersebut. Dikalangan peneliti ingin memahami lebih mendalam mengapa nanopartikel dapat memiliki sifat atau fungsi yang berbeda dari material sejenis dalam ukuran besar (bulk). Dua hal utama yang membuat nanopartikel berbeda dengan material sejenis dalam ukuran besar yaitu: (a) karena ukurannya yang kecil, nanopartikel memiliki nilai perbandingan antar luas permukaan dan volume yang lebih besar jika dibandingkan dengan partkel sejenis dalam ukuran besar. Ini membuat nanopartikel bersifat lebih reaktif. Reaktivitas material ditentukan oleh atomatom di permukaan, karena hanya atomatom tersebut yang akan bersentuhan langsung dengan material lain; (b) ketika ukuran partikel menuju orde nanometer, maka hukum fisika yang berlaku lebih didominasi oleh hukum-hukum fisika kuantum (Abdullah, 2008).

Zeolit adalah kristal aluminosilikat berpori, terdiri dari tetrahedral $\mathrm{AlO}^{-4}$ dengan atom $\mathrm{O}$ menghubungkan tetrahedral tetangga. Untuk struktur yang sama sekali mengandung atom silika, kombinasi $\mathrm{SiO}^{-4}$ dengan cara ini menyebabkan silika $\left(\mathrm{SiO}^{-2}\right)$ merupakan bermuatan padat. Setelah penggabungan atom $\mathrm{Al}$ ke dalam kerangka silika, muatan +3 pada $\mathrm{Al}$ membuat kerangka bermuatan negatif, dan membutuhkan kehadiran kerangka kation tambahan ( kation anorganik dan organik) dalam struktur bertujuan untuk menjaga tetap netral. Berdasarkan proses pembentukannya, zeolit dapat dibagi menajadi dua jenis yaitu zeolit alam dan sintesis. Zeolit alam adalah zeolit yang terbentuk melalui proses alam yaitu proses hidrotermal pada batuan beku basa. Zeolit ini biasanya ditemukan didalam celah-celah yang mengisi batuan tersebut. Bentuk zeolit alam banyak mengandung perbandingan yang besar dari $\mathrm{M}^{2+}$ dan $\mathrm{H}^{+}$pada $\mathrm{Na}^{+}, \mathrm{K}^{+}$, dan $\mathrm{Ca}^{2+}$. Sedangkan zeolit sintesis merupakan zeolit yang sengaja dibuat dari bahan kimia dengan sifat yang hampir sama dengan zeolit alam walaupun zeolit sintesis memiliki sifat fisis yang jauh lebih baik serta mengandung kation $\mathrm{Na}^{+}$dan $\mathrm{K}^{+}$. Zeolit sintesis biasanya dibuat untuk mendapatkan zeolit dengan kemurnian yang lebih baik dengan mengatur perbandingan $\mathrm{Si} / \mathrm{Al}$ yang diinginkan. (Dutta, 2000).

Zeolit juga dikenal sebagai
"saringan molekul" dapat mengatur masuknya molekul yang lebih besar dari pori-pori dan mengizinkan masuk molekul yang lebih kecil. Dengan zeolit sebagai membran, oleh karena itu diharapkan untuk mencapai pemisahan molekul-selektif berdasarkan ukuran dan bentuk secara terus-menerus. Selain itu, zeolit memiliki beberapa sifat yang melekat: sifat hydrophilic atau organophilic dan penyerapan molekul polar bersifat selektif karena medan elektrostatik dasar dalam pori-pori. Dari penggabungan sifat fisik dan kimia yang unik, membran zeolit sangat menarik untuk pemisahan berbagai campuran kimia yang mengandung molekul yang tidak terserap atau campuran dari gas/uap atau air/organik (Hosokawa, 2007).

Kegunaan zeolit sangat luas dalam bidang agrikultural, holtikultural, rumah tangga, industri, pengolahan air, dan pengolahan air limbah. kaitannya dalam bidang industri pengolahan air dan limbah, zeolit digunakan sebagai penyerab, pengemban katalis dan penghilang logam berat. Untuk berbagai aplikasi diperlukan zeolit dengan kualitas yang baik. Dua cara yang digunakan untuk menambah kualitas zeolit yaitu: a). aktivasi secara fisis berupa pemanasan zeolit dengan tujuan untuk menguapkan air yang terperangkap dalam pori-pori kristal zeolit, sehingga luas permukaan pori-pori bertambah. Aktivasi dengan pemanasan ini sering juga dikenal dengan kalsinasi. b). Aktivasi secara kimiawi dilakukan dengan asam atau basa, dengan tujuan untuk membersihkan permukaan pori, membuang senyawa pengotor, dan mengatur kembali letak atom 
yang dapat dipertukarkan. Sebagian peneliti memakai penggabungan dari kedua metode tersebut untuk mencapai hasil yang diinginkan. Disamping tergantung dari metode, hasil akhir dari modifikasi zeolit alam sangat dipengaruhi dari jenis bahan bakunya (Buchori dkk, 2003).

Pada pembuatan nanozeolit perlu diperhatikan seperti rasio massa bola penggiling terhadap serbuk (ball to powder ratio) yang digunakan pada penelitian adalah 8:1 dengan syarat kondisi serbuk dan bola penghancur di dalam jar yang tidak boleh melebihi $2 / 3$ volume jar. Sehingga $1000 \mathrm{rpm}$ selama 6 jam didapatkan ukuran 75-100 nm dengan karakterisasi SEM. Pada penelitian Mukhtar dkk, (2013) membuat nanozeolit dengan wet milling dengan variasi waktu 4, 6, dan 8 jam, sehingga diperoleh grafik pertumbuhan nanozeolit mendekati ukuran $160 \mathrm{~nm}$ pada waktu 8 jam dengan ukuran morfologi permukaan cendrung berbentuk bola dan tidak beraturan. Penelitian Wahyudi dkk, (2010), zeolit jenis mordenit asal Nanggung, Jawa Barat yang telah dikeringkan pada suhu $105^{\circ} \mathrm{C}$ dan digerus hingga berukuran kurang dari 325 mesh dengan jaw crusher dan ring mill. Sampel zeolit yang telah dihaluskan kemudian dimasukkan ke dalam PBM (Planetary Ball Mill) dengan variasi waktu penggilingan $10 \mathrm{jam}, 30 \mathrm{jam}$, dan 60 jam secara basah (wet milling) dengan batuan metanol, sehingga diperoleh partikel 42,9 $\mathrm{nm}$. Proses alat ultrasonikasi pada sampel selama 30 menit yang dihasilkan dari proses penggilingan 10 jam masih tampak menggumpal/teraglomerasi akibat gaya Van der walls antar partikel.

Penelitian ini membentuk nanozeolit alam yang berasal dari Kecamatan Pahae Kabupaten Tapanuli Utara Provinsi Sumatera Utara denggan menggunakan metode top-down dan perlu dilakukan beberapa tinjauan kondisi penggilingan yang memberikan pengaruh pembentukan zeolit berukuran nano, waktu penggilingan, kecepatan perputaran milling dan alat pembuatan nanopartikel.
Kemudian sampel dikarakterisasi dengan menggunakan Instrument Scanning Electron Microscopy (SEM), X-Ray Difraction (XRD), dan EDX.

\section{METODE PENELITIAN}

Bahan : Zeolit Alam Pahae, HCL dan aquades

Alat : neraca analitik, magnetik stirrer, gelas ukur, erlenmeyer, pipet tetes, kertas saring watchman 42, corong, oven, centrifuse, furnace, Planetary Ball Milling 200, XRD, SEM dan EDX

Penelitian ini dilaksanakan di Laboratorium Kimia dan Laboratorium Fisika Unimed. Karakterisasi dilakukan di Laboratorium Nanotech Indonesia Bandung. Zeolit diambil dari Pahae dalam bentuk bongkahan. Zeolit dihancurkan (crushing) lalu dimasukkan kedalam ballmill selama satu jam untuk mendapatkan ukuran yang lebih kecil (kira-kira ukuran pasir). Zeolit selanjutnya diayak dengan menggunakan ayakan 200 mesh. Zeolit berukuran 200 diaktivasi secara kimia dengan larutan HCL 2M dengan komposisi 50 gram zeolit alam direndam $150 \mathrm{ml}$ pelarut (b/V), kemudian diaduk selama 4 jam menggunakan magnetik stirrer. Aktivasi secara asam bertujuan untuk meningkatkan rasio $\mathrm{Al} / \mathrm{Si}$.

Pembuatan nanozeolit dilakukan dengan metode top-down dengan menggunakan planetary ball mill PM 200 yaitu dengan ketentuan rasio antara ukuran sampel dan bola penggiling yaitu 1:4 dan volume keseluruhan tidak boleh lebih dari $2 / 3$ volume jar. Proses milling berlangsung dengan waktu 24 jam pada kecepatan 500 rpm. Tabung ( jar) dan bola penggiling sebelum digunakan dicuci terlebih dahulu menggunakan etanol. Zeolit hasil milling dikarakterisasi menggunakan XRD, SEM dan EDX untuk diketahui ukuran, morfologi, dan struktur.

\section{HASIL PENELITIAN DAN PEMBAHASAN}


Metode difraksi sinar-X digunakan menentukan jenis kristal berdasarkan pola difraksi sinar-X suatu kristal yang bersifat khas. Pola difraksi ini ditentukan oleh susunan atom dalam kristal. Pada penelitian ini dilakukan karakterisasi XRD pada kristal nanozeolit Pahae. Gambar 1 adalah pola difraksi kristal nanozeolit Pahae.

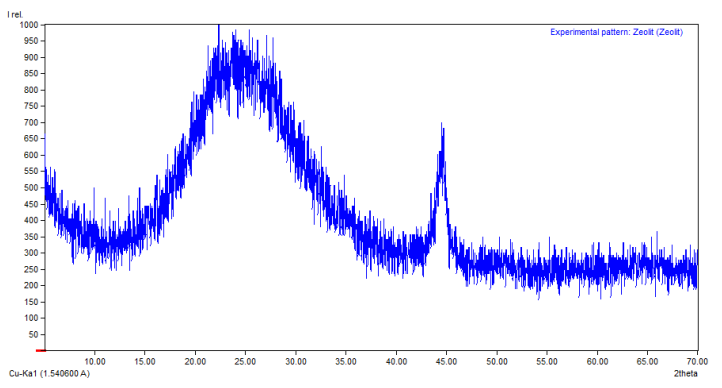

Gambar 1. Hasil Pola Difraksi XRD Dari Zeolit

Abdullah (2008) menjelaskan untuk menentukan ukuran partikel dapat digunakan dengan metode Scherrer. Ukuran kristalin ditentukan berdasarkan pelebaran puncak difraksi sinar-X yang muncul. Metode ini menjelaskan satu partikel mengandung sejumlah kristallites yang kecil-kecil maka informasi yang diberikan metode ini adalah ukuran kristallin. Untuk partikel berukuran nanometer, biasanya satu partikel hanya mengandung satu kristallites. Berdasarkan hasil perhitungan, didapatkan zeolit alam untuk penggilingan selama 24 jam memiliki ukuran kristal rata-rata 85,44 nm. Pada penelitian sebelumnya yang dilakukan oleh Liherlinah (2009), penentuan ukuran partikel nano $\mathrm{CuO} / \mathrm{ZnO} / \mathrm{Al}_{2} \mathrm{O}_{3}$ dengan metode Scherer yang ditentukan berdasarkan pelebaran puncak difraksi sinar-X. dengan berasumsi untuk partikel berukuran nanometer, biasanya partikel hanya mengandung satu kristallites. Dengan ukuran seperti ini dikatakan sebagai nanopartikel kristalin yang tampak dari luar yang diamati SEM (grain size). FWHM yang besar menunjukkan semakin kecil ukuran kristal. Hasil XRD pada gambar 1 terlihat bentuk pola difraksi yang amorf. Menurut Charkhi dkk (2010) pembentukan amorf pada kristallin zeolit dapat dipengaruhi struktur ikatan Si-O-Si dan Si-O-Al dan rusaknya struktur kristal asli di bawah tindakan kekuatan mekanik yang menyeluruh. Penelitian Wahyudi (2010) dengan peningkatan waktu penggilingan terbentuk pola difraksi yang amorf pada 8 jam penggilingan. Akibat dari penggilingan terlalu lama ukuran partikel menjadi kecil, luas permukaan dan energi permukaannya menjadi tinggi. Namun ikatan $\mathrm{Si}-\mathrm{O}$ dan $\mathrm{Mg}-\mathrm{O}$ telah rusak dengan pertambahan waktu milling, mengakibatkan struktur mineral hilang ditunjukkan dengan kurva difraktogram yang landai. Penelitian yang dilakukan oleh Charkhi dkk (2010), zeolit mengalami pengurangan sifat kristal antara $55-100 \%$ pada ukuran antara $100 \mathrm{~nm}-30$ $\mu \mathrm{m}$ dilihat dari perbedaan pola difraksi kristal zeolit milling dengan selang waktu antara $1 \mathrm{~s} / \mathrm{d} 8 \mathrm{jam}$. Hal ini diakibatkan mendapatkan perlakuan kecepatan milling $500 \mathrm{rpm}$, waktu milling 3 jam, dengan zeolit 4,5\% dari berat bola penggiling dan perbandingan volume air dengan berat zeolit adalah 1:1. Menurut penelitian Lestari (2010) keadaan amorf sampel diakibatkan oleh beberapa kelemahan, diantaranya mengandung banyak pengotor serta kristalinitasnya kurang baik.

Dari hasil karakterisasi SEM yang disajikan dalam gambar 2 dapat dilihat bentuk morfologi nanozeolit alam Pahae. Pada gambar terlihat zeolit mengalami penggumpal di berbagai titik, hal ini dapat diakibatkan karena pencampuran yang tidak homogen dan pemanasan yang tidak homogen. Hal ini sesuai dengan penelitian Suryanarayana (2001) ukuran partikel semakin membesar akibat waktu penggilingan, ini dikarenakan semakin lama waktu yang diperlukan untuk melakukan proses penggilingan maka akan sering terjadi tumbukan dan hal itu akan menyebabkan temperatur di dalam jar 
bertambah dan akan mempengaruhi hasil sampel yang didapatkan terutama saat sampel tersebut rawan terhadap perubahan suhu. Sehingga semakin lama waktu penggilingan, bila melampaui batas optimal, dapat menyebabkan penggumpalan yang berlebihan dan mengakibatkan penambahan ukuran partikel.

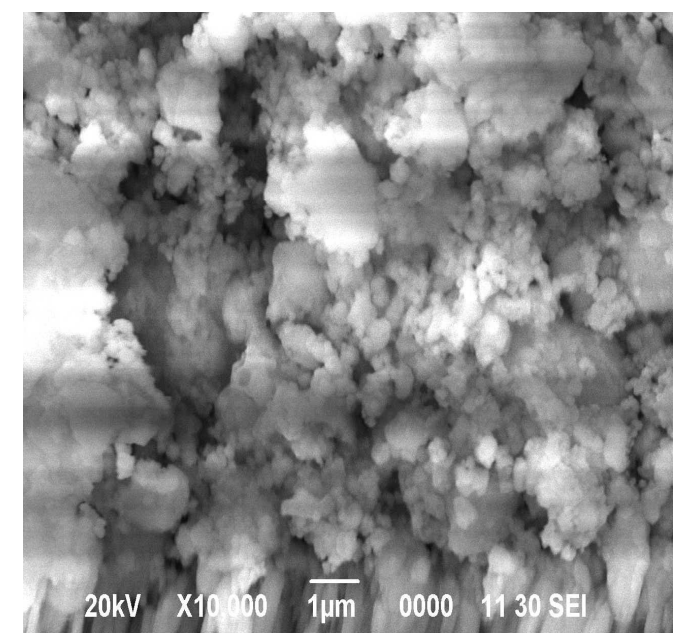

Gambar 2. Morfologi Nanozeolit Menggunakan Sem Perbesaran 10000X

Komposisi zeolit yang diperoleh didapat dari hasil EDX seperti pada Tabel 1 di bawah ini. Zeolit terdiri dari silikon $(43,75 \%)$, Oksigen $(42,66 \%)$, Aluminium (7,72\%), Besi (6,39\%), Kalium (3,3\%). Dari Tabel 1 diperoleh bahwa nanozeolit memilki sifat-sifat yang cukup baik dan memilki material silika yang sangat banyak dengan perbandingan $\mathrm{Si} / \mathrm{Al}$ $43,75 / 7,72=5,66$, untuk jenis mordenit perbandingan $\mathrm{Si} / \mathrm{Al}$ adalah 4,17 hingga 10 , (Chai Mee Kin, 2001). Hal ini sesuai dengan penelitian Bukit (2011), zeolit memiliki perbadingan $\mathrm{Si} / \mathrm{Al}=5,65, \mathrm{Si}$ yang lebih tinggi menunjukkan zeolit bersifat hidrofobik dan mempunyai affinitas terhadap hidrokarbon.

Tabel 1. Komposisi Kimia Zeolit

\begin{tabular}{|l|l|}
\hline Komposisi kimia & Zeolit \% \\
\hline Oksigen $(\mathrm{O})$ & 42,66 \\
\hline
\end{tabular}

\begin{tabular}{|l|l|}
\hline Alumunium(Al) & 7,72 \\
\hline Silikon $(\mathrm{Si})$ & 43,75 \\
\hline Kalium $(\mathrm{K})$ & 3,312 \\
\hline Besi $(\mathrm{Fe})$ & 6,398 \\
\hline Total & 100 \\
\hline
\end{tabular}

\section{KESIMPULAN DAN SARAN}

Telah dapat dibuat nanozeolit alam Pahae dengan ukuran rata-rata 85,44 $\mathrm{nm}$. Metode yang digunakan adalah metode top-down dengan alat Planetary Ball Milling PM 200. Hasil SEM menunjukkan permukaaan nanozeolit masih ada penggumpalan (aglomerasi) dan ukurannya kurang merata. Hasil EDX diperoleh kandungan zeolit terdiri dari silikon $(43,75 \%)$, Oksigen $(42,66 \%)$, Aluminium dan $(7,72 \%)$, Besi $(6,39 \%)$, Kalium $(3,3 \%)$.

Untuk mendapatkan hasil partikel yang merata dan ukuran yang lebih kecil maka disarankan perlu dilakukan penggilingan lebih lama dan kecepatan putarnya lebih besar. Untuk mengatasi penggumpalan perlu dilakukan penyinaran dengan alat ultrasonikator.

\section{DAFTAR PUSTAKA}

Abdullah, M.,(2008), Pengantar Nanosains, FMIPA, ITB Bandung

Abdullah, M., Yudistira., Nirmin dan Khairurrijal.,(2008), Sintesis Nanopartikel. Jurnal Nanosains \& Nanoteknologi. 1 : 33-57

Buchori, L., Budiyono, (2003)Aktivasi Zeolit Dengan menggunakan Perlakuaan Asam dan

Kalsinasi,Seminar Nasional Teknik Kimia Indonesia, Yogyakarta.

Bukit, N., (2011), Pengolahan Zeolit alam Sebagai bahan pengisi nano komposit polipropina dan karet alam SIR-20 dengan kompatibeliser anhidrida mateat- 
grafted-polipropilena, Disertasi USU, Medan

Chai Mee Kin, Asian Hussain, dan Zainab Ramli, (2001), "penentuan kapasiti dan jenis pencerapan Zeolit asli terhadap bahan pencelup sintetik" Malaysian Journal of Analytical Sciences, Vol. 7, No.1(2001) 69-79

Charkhi, A., Hossein, K., dan Mohammad, K., (2010), Optimized experimental design for natural clipnoptilolite zeolite ball milling to produce nano powder, Powder technology 203:2: 389-396

Dutta, K., (2000). Hand Book of Zeolite Science and Technology. The Ohio State University

Hosokawa, M., (2007), Naoparticle Technology Handbook, Hosolawa micron corporation.

Lestari, D.Y., (2010), Kajian Modifikasi Dan Karakterisasi Zeolit Alam Dari Berbagai Negara, Prosiding Seminar Nasional Kimia dan Pendidikan Kimia, Yogyakarta.

Liherlinah, Abdullah,M, dan Khairurrijal, (2009). Sintesis Nanokatalis

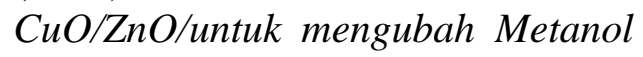
menjadi Hidrogem untuk bahan bakar kendaraan fuel Cell, Jurnal Nanosains dan Teknologi, FMIPA,ITB. ISSN 1979-0880.

Suryanarayana, C., 2001. Mechanical Alloying and Milling. Progeress in Material Science

Mukhtar, Borhan, abdullah, dan Rusop (2013), Nanozeolite Produced By Wet Milling At Different Milling Time, Nano-SciTech Centre, Institute of Science, Universiti Teknologi MARA, Selangor, Malaysia,

Wahyudi, Agus, Dessy, Sariman, dan Siti, (2010), Sintesis Nanopartikel Zeolit Secara Top Down Menggunakan Planetary Ball Milling Dan Ultrasinikator, Pusat Penelitian dan Pegembangan Teknologi Mineral dan Barubara ( Tekmira ). 